\title{
EFFECT OF DIFFERENT IRRIGATING SOLUTIONS AND MECHANICAL AIDS ON THE REMOVAL OF CALCIUM HYDROXIDE INTRA-CANAL MEDICATION FROM STRAIGHT AND CURVED CANALS
}

\author{
Soliman M. Kamha* and Emad M. Khattab ${ }^{* *}$
}

\begin{abstract}
Aim: to study effect of different irrigating solutions and mechanical aids on $\mathrm{Ca}(\mathrm{OH}) 2$ removal from straight and curved canals.

Materials and Methods: Forty five maxillary central incisors with straight roots (group I) were prepared with step back technique until apical size 55 and forty five mandibular first molars with curved mesio buccal canals (group II) prepared with Pro Taper universal system up to apical size F2. Calcium hydroxide was applied into all canals and the accesses were sealed with temporary dressing. All teeth were placed in wax mould and digital radiographs were taken to confirm canal filling with $\mathrm{Ca}(\mathrm{OH}) 2$ to length. Every group was subdivided into 3 subgroups according to the irrigating solution used; subgroup A irrigated with $5.25 \% \mathrm{NaOCl}$ only, subgroup B irrigated with $5.25 \% \mathrm{NaOCl}$ and $10 \% \mathrm{H} 2 \mathrm{O} 2$, and subgroup $\mathrm{C}$ irrigated with $5.25 \% \mathrm{NaOCl}$ and $17 \%$ EDTA. Every subgroup was further subdivided into 3 subgroups (1,2, and 3 ) according to the mechanical aid for $\mathrm{Ca}(\mathrm{OH}) 2$ removal; in subgroup 1 used master apical file, in subgroup 2 used master apical file and apical patency, in subgroup 3 used master apical file, apical patency and increase in canal size. Post removal digital radiographs were taken for all teeth in their wax mould. Any traces of $\mathrm{Ca}(\mathrm{OH}) 2$ were traced by "Image J" software and estimated as a percentage to the total canal space and statistically analyzed.
\end{abstract}

Results: There was no significant difference between the subgroups A, B, and C in anterior and posterior teeth either in subgroup 1,2 , or 3 . In anterior teeth group, there were significant differences between subgroups 1,2 , and 3 in subgroup B and C but, in subgroup A, there was no significant difference. In posterior teeth group, there was a significant difference between subgroups 1,2 , and 3. in subgroup A but, in subgroup B and C, there was no significant difference. Anterior and posterior teeth were compared and the results were significant differences in subgroups A1 and A2 but, in subgroup A3 there was no significant difference. In subgroup B, there were significant differences in subgroups B1, B2 and B3. In subgroup C, there was no significant difference in subgroups $\mathrm{C} 1, \mathrm{C} 2$ and $\mathrm{C} 3$.

Conclusions: Under the tested conditions of this study, the most successful method of $\mathrm{Ca}(\mathrm{OH}) 2$ removal was the use of master apical file (hand or rotary), apical patency and increase one size filing with the combination of EDTA and $\mathrm{NaOCl}$ irrigation in both anterior \& posterior teeth.

KEYWORDS: Removal of calcium hydroxide, calcium hydroxide intra-canal medicaments.

Lecturer of Endodontics, Faculty of Dentistry, Pharos University

** Associate Professor of Endodontics, Faculty of Dentistry, King Abdulaziz University, Saudi Arabia. 


\section{INTRODUCTION}

Chemo-mechanical cleaning in one visit might not be able to totally eliminate infection. Hence, the need for intra-canal medication cannot be neglected during endodontic treatment of infected teeth. Calcium hydroxide has been well accepted as an intra-canal medicament ${ }^{[1]}$.

Research focused on the mode of action, biocompatibility, and the time needed for $\mathrm{Ca}(\mathrm{OH}) 2$ to be kept in canals. The best antibacterial effect was proposed to be 1-4 weeks, and $\mathrm{Ca}(\mathrm{OH}) 2$ was found to have good antibacterial effect against the majority of endodontic pathogens. It is also biocompatible with host tissues and helps in inhibition of tooth resorption and induction of repair by hard tissue formation ${ }^{[2]}$.

Calcium hydroxide was found to be the best medicament to induce hard tissue deposition and promote healing of vital pulpal and periapical tissues ${ }^{[3]}$. The main characteristics of $\mathrm{Ca}(\mathrm{OH}) 2$ include limited solubility, high $\mathrm{pH}$, use as a broadspectrum antimicrobial agent, and the ability to sustain antimicrobial action for long periods [4,5].

Concern about the effect of residual traces of $\mathrm{Ca}(\mathrm{OH}) 2$ on the sealing ability of obturation materials has been raised. Creation of voids in the root canal treatment that were not properly filled was reported ${ }^{[6]}$. Complete removal of $\mathrm{Ca}(\mathrm{OH}) 2$ was recommended before obturation to exclude any negative interface between medication and filling material and to allow maximum adherence of the sealer to the root canal wall ${ }^{[7]}$.

Incomplete removal of calcium hydroxide from the canal surface prevented sealer from penetrating into the dentinal tubules resulting in a potential reduction of sealer adaptation ${ }^{[8]}$. The remnant of calcium hydroxide could react chemically with the sealer reducing its flow and working time ${ }^{[9]}$. Therefore, it is mandatory to remove calcium hydroxide intra-canal medicament before root canal filling ${ }^{[10]}$.
The most frequently described method for removing calcium hydroxide from the root canal is recapitulation with the master apical file in combination with copious irrigation ${ }^{[11-13]}$.

It is difficult to remove calcium hydroxide from the root canals of mandibular molars by conventional methods ${ }^{[14]}$. The effect of canal curvature on the ability to remove $\mathrm{Ca}(\mathrm{OH}) 2$ was studied. Curved canal with apical transportation will result in insufficient calcium hydroxide removal. Endo Activator, pre-curved ultrasonic file, and finishing file are more effective in the curved root canal with apical transportation ${ }^{[15]}$.

Many studies were conducted to get the optimum results to remove calcium hydroxide from the root canals. Sodium hypochlorite, citric acid and EDTA were used, and none of the irrigants or respective combinations was able to completely remove the calcium hydroxide from the root canals ${ }^{[16]}$.

Some investigators evaluated the irrigation techniques either by syringe or passive ultrasonic irrigation; they found remnants of calcium hydroxide medicament in all experimental groups ${ }^{[17,18]}$. Irrigating solutions and ultrasonic activation of the irrigating solution could not remove calcium hydroxide completely from simulated immature root canal ${ }^{[19.20]}$.

Capar et al $2014{ }^{[21]}$ compared the efficacy of conventional syringe, ultrasonic, Endo Vac and Self-Adjusting file irrigation systems in removing calcium hydroxide from simulated root canal irregularities. They concluded that, the use of the Self-Adjusting file with the combination of EDTA and $\mathrm{NaOCl}$ enhanced calcium hydroxide removal when compared with the use of only $\mathrm{NaOCl}$ with the Self-Adjusting file. Continuous passive ultrasonic irrigation and Self-Adjusting file were more effective than Endo Vac, and conventional syringe irrigation in the removal of calcium hydroxide medicament. 
Since all studies failed to achieve complete removal of $\mathrm{Ca}(\mathrm{OH}) 2$ from root canals, the present study was conducted to evaluate other combinations of irrigating solutions and mechanical aids on the ability to eliminate $\mathrm{Ca}(\mathrm{OH}) 2$ residues from straight and curved canals.

\section{MATERIALS AND METHODS}

This study was performed on extracted teeth having different canal shapes in order to represent straight and curved canals. Both anterior and posterior teeth were used.

\section{Sample selection}

Anterior teeth: 45 freshly extracted maxillary central incisors with straight roots. Posterior teeth: 45 mandibular first molar were selected. All teeth were examined visually and radiographically. Teeth with cracks, canal calcification, and external or internal resorption were excluded. All teeth had patent canals.

\section{Preparation to receive calcium hydroxide}

All teeth were accessed. Canals were explored, and patency was confirmed with size $10 \mathrm{~K}$ file. The distal roots of posterior teeth were cut to the cervical level and their orifices were sealed with glass ionomer filling material (Medifil, Promedica, Germany). This was done to avoid superimposition in case of proximal radiograph exposures were needed.

For anterior teeth, the initial file size was determined. Canal preparation with the step back technique was performed to achieve an apical preparation size 55, and finished till size 3 Gates Glidden drill, for purpose of standardization of canal size.

For posterior teeth, the ProTaper Universal system (Dentsply Maillefer, Switzerland) was used up to F2 (size $25,8 \%$ apical taper).

$5.25 \%$ sodium hypochlorite was used in between file sizes.

\section{Application of calcium hydroxide}

Canals were dried with paper points. Then $\mathrm{Ca}(\mathrm{OH}) 2$ (Metapex, Meta, Biodent) was applied using the tip of the $\mathrm{Ca}(\mathrm{OH}) 2$ syringe. A cotton pellet was placed in the pulp chamber and a temporary dressing (Cavit, 3M, Espe, France) was applied to seal the access. A digital radiograph (Sopix 2, Soprodigital imaging, France) was taken to confirm canal filling with $\mathrm{Ca}(\mathrm{OH}) 2$ to length.

\section{Placement of teeth in a wax mould}

The purpose of this step was to create a closed system representing natural teeth with a barrier of apical periodontium to avoid false results upon removal of $\mathrm{Ca}(\mathrm{OH}) 2$ from the canals. Another purpose was to standardize the radiographic exposures for comparison.

\section{Pre-removal radiographs}

Teeth, in their wax mould, were digitally radiographed and saved to be compared later on.

\section{Storage of teeth}

Teeth were stored in tap water for seven days to simulate clinical conditions where $\mathrm{Ca}(\mathrm{OH}) 2$ medication are usually left in the canals for 7-10 days to achieve the antibacterial effect.

\section{Grouping}

Teeth were divided into two main groups according to the type of teeth as follows:

Group I: Anterior teeth (45 teeth)

Group II: Posterior teeth (45 teeth)

Each group was subdivided into three subgroups of 15 teeth each according to the irrigating solution as follows:

Subgroup A: $5.25 \% \mathrm{NaOCl}$ was used as irrigating solution.

Subgroup B: $5.25 \% \mathrm{NaOCl}$ and $10 \% \mathrm{H} 2 \mathrm{O} 2$ were used as irrigating solutions. 
Subgroup C: $5.25 \% \mathrm{NaOCl}$ and $17 \%$ EDTA were used as irrigating solutions.

Each subgroup was further subdivided into three subgroups of five teeth each according to the mechanical aid as follows:

Subgroup 1: removal of $\mathrm{Ca}(\mathrm{OH}) 2$ by the irrigating solution and master apical file.

Subgroup 2: removal of $\mathrm{Ca}(\mathrm{OH}) 2$ by the irrigating solution and master apical file and apical patency file.

Subgroup 3: removal of $\mathrm{Ca}(\mathrm{OH}) 2$ by the irrigating solution and master apical file, apical patency file, and increase in canal size.

Grouping and subgrouping is represented in (Table 1).

\section{Post-removal radiographs}

Teeth, in their wax mould, were digitally radiographed again after $\mathrm{Ca}(\mathrm{OH}) 2$ removal and saved to be compared with pre-removal radiographs.

\section{Detailed description of removal protocols}

For subgroup A, where $5.25 \% \mathrm{NaOCl}$ was used as irrigating solutiom with master apical file, $\mathrm{NaOCl}$ solution was delivered inside the canal about 2-3 $\mathrm{mm}$ from the apical terminus using a side venting needle gauge 31 (Steri Irrigation Tips, Diadent). Then the master apical file was introduced to length and moved up and down few times. It was cleaned with wet gauze. Then, the procedure of irrigation and master apical file insertion and removal was repeated many times until the solution came out clear, as seen by the naked eye, and no more $\mathrm{Ca}(\mathrm{OH}) 2$ traces could be seen on the file.

For subgroup A, where $5.25 \% \mathrm{NaOCl}$ was used as irrigating solutiom with master apical file and apical patency file, $\mathrm{NaOCl}$ solution was delivered in the same previous way. Then the master apical file was inserted to the length and moved up and down few times. It was removed and fresh solution was delivered. A size $10 \mathrm{~K}$ patency file was introduced $1 \mathrm{~mm}$ beyond the foramen. The procedure was repeated many times until the solution came out clear, as seen by the naked eye, and no more $\mathrm{Ca}(\mathrm{OH}) 2$ traces could be seen on the file.

For subgroup A, where $5.25 \% \mathrm{NaOCl}$ was used as irrigating solution with master apical file, apical patency file and file one size larger, $\mathrm{NaOCl}$ solution was delivered in the same previous way. Then the master apical file was inserted to the length and moved up and down few times. It was removed and fresh solution was delivered. A size $10 \mathrm{~K}$ patency file was introduced $1 \mathrm{~mm}$ beyond the foramen. The canal was filed one size larger than the master apical file i.e. one larger $\mathrm{K}$ file for anterior teeth and F3 ProTaper for posterior teeth. Then solution delivery and repeated insertion of master apical file and patency file were done until the solution came out clear, as seen by the naked eye, and no more $\mathrm{Ca}(\mathrm{OH}) 2$ traces could be seen on the file.

For subgroup B, where both $10 \% \mathrm{H} 2 \mathrm{O} 2$ and $5.25 \% \mathrm{NaOCl}$ were used as irrigating solution, irrigation was started by delivering $\mathrm{H} 2 \mathrm{O} 2$ followed by $\mathrm{NaOCl}$. Then the master apical files were used without, with patency file, or with increase in file size according to subgrouping until the solution came out clear, as seen by the naked eye, and no more $\mathrm{Ca}(\mathrm{OH}) 2$ traces could be seen on the file.

For subgroup $\mathrm{C}$, where both $5.25 \% \mathrm{NaOCl}$ and $17 \%$ EDTA were used as irrigating solution, irrigation was started by delivering EDTA followed by $\mathrm{NaOCl}$. Then the master apical files were used without, with patency file, or with increase in file size according to subgrouping until the solution came out clear, as seen by the naked eye, and no more $\mathrm{Ca}(\mathrm{OH}) 2$ traces could be seen on the file. The final irrigation was done by EDTA.

The same procedures were done according to grouping and subgrouping 
TABLE (1) Grouping and subgrouping.

\begin{tabular}{|c|c|c|c|c|c|c|c|c|}
\hline \multicolumn{9}{|c|}{ Group I (Anterior teeth) $n=45$} \\
\hline \multicolumn{3}{|c|}{$\begin{array}{c}\text { Subgroup A ( } \mathrm{NaOCl}) \\
n=15\end{array}$} & \multicolumn{3}{|c|}{$\begin{array}{c}\text { Subgroup B }(\mathrm{NaOCl}+\mathrm{H} 2 \mathrm{O} 2) \\
n=15\end{array}$} & \multicolumn{3}{|c|}{$\begin{array}{c}\text { Subgroup } \mathrm{C}(\mathrm{NaOCl}+\text { EDTA }) \\
\mathrm{n}=15\end{array}$} \\
\hline $\begin{array}{c}\text { Subgroup } \\
\text { A1 } \\
\text { Irrigating } \\
\text { solution + } \\
\text { MAF } \\
n=5\end{array}$ & $\begin{array}{c}\text { Subgroup } \\
\text { A2 } \\
\text { Irrigating } \\
\text { solution } \\
+ \text { MAF } \\
\text { + Apical } \\
\text { patency } \\
\mathrm{n}=5\end{array}$ & $\begin{array}{c}\text { Subgroup } \\
\text { A3 } \\
\text { Irrigating } \\
\text { solution } \\
\text { + MAF } \\
\text { + Apical } \\
\text { patency + } \\
\text { Increase one } \\
\text { size filing } \\
\mathrm{n}=5\end{array}$ & $\begin{array}{c}\text { Subgroup } \\
\text { B1 } \\
\text { Irrigating } \\
\text { solution + } \\
\text { MAF } \\
n=5\end{array}$ & $\begin{array}{c}\text { Subgroup } \\
\text { B2 } \\
\text { Irrigating } \\
\text { solution } \\
+ \text { MAF } \\
+ \text { Apical } \\
\text { patency } \\
n=5\end{array}$ & $\begin{array}{c}\text { Subgroup } \\
\text { B3 } \\
\text { Irrigating } \\
\text { solution } \\
\text { + MAF } \\
\text { + Apical } \\
\text { patency + } \\
\text { Increase one } \\
\text { size filing } \\
\mathrm{n}=5\end{array}$ & $\begin{array}{l}\text { Subgroup } \\
\text { C1 } \\
\text { Irrigating } \\
\text { solution + } \\
\text { MAF } \\
n=5\end{array}$ & $\begin{array}{c}\text { Subgroup } \\
\text { C2 } \\
\text { Irrigating } \\
\text { solution } \\
+ \text { MAF } \\
+ \text { Apical } \\
\text { patency } \\
\mathrm{n}=5\end{array}$ & $\begin{array}{c}\text { Subgroup } \\
\text { C3 } \\
\text { Irrigating } \\
\text { solution } \\
\text { + MAF } \\
\text { + Apical } \\
\text { patency + } \\
\text { Increase one } \\
\text { size filing } \\
\mathrm{n}=5\end{array}$ \\
\hline \multicolumn{9}{|c|}{ Group II (Posterior teeth) $n=45$} \\
\hline \multicolumn{3}{|c|}{$\begin{array}{l}\text { Subgroup A ( } \mathrm{NaOCl}) \\
n=15\end{array}$} & \multicolumn{3}{|c|}{$\begin{array}{c}\text { Subgroup B }(\mathrm{NaOCl}+\mathrm{H} 2 \mathrm{O} 2) \\
\mathrm{n}=15\end{array}$} & \multicolumn{3}{|c|}{$\begin{array}{c}\text { Subgroup } \mathrm{C}(\mathrm{NaOCl}+\mathrm{EDTA}) \\
\mathrm{n}=15\end{array}$} \\
\hline $\begin{array}{c}\text { Subgroup } \\
\text { A1 } \\
\text { Irrigating } \\
\text { solution + } \\
\text { MAF } \\
n=5\end{array}$ & $\begin{array}{c}\text { Subgroup } \\
\text { A2 } \\
\text { Irrigating } \\
\text { solution } \\
+ \text { MAF } \\
\text { + Apical } \\
\text { patency } \\
\mathrm{n}=5\end{array}$ & $\begin{array}{c}\text { Subgroup } \\
\text { A3 } \\
\text { Irrigating } \\
\text { solution } \\
\text { + MAF } \\
\text { + Apical } \\
\text { patency + } \\
\text { Increase one } \\
\text { size filing } \\
\mathrm{n}=5\end{array}$ & $\begin{array}{c}\text { Subgroup } \\
\text { B1 } \\
\text { Irrigating } \\
\text { solution + } \\
\text { MAF } \\
n=5\end{array}$ & $\begin{array}{c}\text { Subgroup } \\
\text { B2 } \\
\text { Irrigating } \\
\text { solution } \\
+ \text { MAF } \\
+ \text { Apical } \\
\text { patency } \\
n=5\end{array}$ & $\begin{array}{c}\text { Subgroup } \\
\text { B3 } \\
\text { Irrigating } \\
\text { solution } \\
\text { + MAF } \\
\text { + Apical } \\
\text { patency + } \\
\text { Increase one } \\
\text { size filing } \\
\mathrm{n}=5\end{array}$ & $\begin{array}{c}\text { Subgroup } \\
\text { C1 } \\
\text { Irrigating } \\
\text { solution + } \\
\text { MAF } \\
n=5\end{array}$ & $\begin{array}{c}\text { Subgroup } \\
\text { C2 } \\
\text { Irrigating } \\
\text { solution } \\
+ \text { MAF } \\
+ \text { Apical } \\
\text { patency } \\
\mathrm{n}=5\end{array}$ & $\begin{array}{c}\text { Subgroup } \\
\text { C3 } \\
\text { Irrigating } \\
\text { solution } \\
\text { + MAF } \\
\text { + Apical } \\
\text { patency + } \\
\text { Increase one } \\
\text { size filing } \\
\mathrm{n}=5\end{array}$ \\
\hline
\end{tabular}

\section{Evaluation and scoring}

Any traces of $\mathrm{Ca}(\mathrm{OH}) 2$ that were seen in postradiographs were traced by "Image J" software and estimated in relation to the total canal space from the apex to the cervical line. The percentage of remaining $\mathrm{Ca}(\mathrm{OH}) 2$ from the total canal space were calculated, tabulated and statistically analyzed.

\section{Statistical analysis}

Data were fed to the computer and analyzed using IBM SPSS software package version 20.0. Kruskal Wallis test was used to compare different groups for abnormally distributed quantitative variables and Mann Whitney test was used for comparing each two groups. Significance of the obtained results was judged at the $5 \%$ level.

\section{RESULTS}

\section{Results of group I (Anterior Teeth)}

The mean value and standard deviation of the percentage of remaining $\mathrm{Ca}(\mathrm{OH}) 2$ inside the root canal after removal, in $\mathrm{NaoCl}$ subgroup (Subgroup A), with master apical file (subgroup A1) was 6.77 \pm 7.36 , with master apical file and apical patency (subgroup A2) was $1.63 \pm 1.74$, and with master apical file, apical patency and increase one size filing (subgroup A3) was $12.40 \pm 3.70$. There was no significant difference between them (Table 1).

The mean value and standard deviation of the percentage of remaining $\mathrm{Ca}(\mathrm{OH}) 2$ inside the root canal after removal, in $\mathrm{NaoCl}$ and $\mathrm{H} 2 \mathrm{O} 2$ subgroup (Subgroup B), with master apical file (subgroup B1) was $4.73 \pm 3.89$, with master apical file and apical 
patency (subgroup B2) was $1.04 \pm 1.19$, and with master apical file, apical patency and increase one size filing (subgroup B3) was $1.04 \pm 1.53$. There was a significant difference between them. Also, there was a significant difference between $\mathrm{NaoCl}$ and EDTA subgroup with master apical file and apical patency (subgroup B2), and with master apical file, apical patency and increase one size filing (subgroup B3) when compared with $\mathrm{NaOCl}$ and EDTA with master apical file only (subgroup B1) (Table 2).

The mean value and standard deviation of the percentage of remaining $\mathrm{Ca}(\mathrm{OH}) 2$ inside the root canal after removal, in $\mathrm{NaoCl}$ and EDTA subgroup (Subgroup C), with master apical file (subgroup C1) was $3.18 \pm 1.60$, with master apical file and apical patency (subgroup C2) was $1.23 \pm 0.57$, and with master apical file, apical patency and increase one size filing (subgroup C3) was $0.96 \pm 0.46$. There was a significant difference between them. Also, there was a significant difference between $\mathrm{NaoCl}$ and EDTA subgroup with master apical file and apical patency (subgroup $\mathrm{C} 2$ ), and with master apical file, apical patency and increase one size filing (subgroup C3) when compared with $\mathrm{NaoCl}$ and EDTA with master apical file only (subgroup C1) (Table 2).

There was no significant difference between $\mathrm{NaoCl}$ subgroup (Subgroup A), $\mathrm{NaoCl}$ and $\mathrm{H} 2 \mathrm{O} 2$ subgroup (Subgroup B), and $\mathrm{NaoCl}$ and EDTA subgroup (Subgroup C) either in using them with master apical file only (subgroup 1), or with master apical file and apical patency (subgroup 2), or with master apical file, apical patency and increase one size (subgroup 3) (Table 2).

\section{Results of group II (Posterior teeth)}

The mean value and standard deviation of the percentage of remaining $\mathrm{Ca}(\mathrm{OH}) 2$ inside the root canal after removal, in $\mathrm{NaoCl}$ subgroup (Subgroup A), with master apical file (subgroup A1) was 25.16 \pm 16.77 , with master apical file and apical patency (subgroup A2) was $16.43 \pm 9.06$, and with master apical file, apical patency and increase one size filing (subgroup A3) was $6.40 \pm 3.62$. There was a significant difference between them. Also, there was a significant difference between $\mathrm{NaoCl}$ with master apical file, apical patency and increase one size filing (subgroup A3) when compared with $\mathrm{NaOCl}$ with master apical file and apical patency (subgroup A2) and $\mathrm{NaOCl}$ with master apical file only (subgroup A1) (Table 2).

The mean value and standard deviation of the percentage of remaining $\mathrm{Ca}(\mathrm{OH}) 2$ inside the root canal after removal, in $\mathrm{NaOCl}$ and $\mathrm{H} 2 \mathrm{O} 2$ subgroup (Subgroup B), with master apical file (subgroup B1) was $22.38 \pm 23.27$, with master apical file and apical patency (subgroup B2) was $16.11 \pm 18.70$, and with master apical file, apical patency and increase one size filing (subgroup B3) was $11.55 \pm 11.86$. There was no significant difference between them (Table 2).

The mean value and standard deviation of the percentage of remaining $\mathrm{Ca}(\mathrm{OH}) 2$ inside the root canal after removal, in $\mathrm{NaoCl}$ and EDTA subgroup (Subgroup C), with master apical file (subgroup C1) was $14.64 \pm 13.89$, with master apical file and apical patency (subgroup C2) was $9.99 \pm 10.02$, and with master apical file, apical patency and increase one size filing (subgroup C3) was 4.35 \pm 3.29 . There was no significant difference between them (Table 2).

There was no significant difference between $\mathrm{NaoCl}$ subgroup (Subgroup A), $\mathrm{NaoCl}$ and $\mathrm{H}_{2} \mathrm{O} 2$ subgroup (Subgroup B), and $\mathrm{NaoCl}$ and EDTA subgroup (Subgroup C) either in using them with master apical file only (subgroup 1), or with master apical file and apical patency (subgroup 2), or with master apical file, apical patency and increase one size (subgroup 3) (Table 2).

\section{Comparison between group I and group II (ante- rior and posterior teeth)}

In $\mathrm{NaoCl}$ subgroup (Subgroup A), there was a significant difference between anterior and posterior teeth when $\mathrm{NaoCl}$ used with master apical file and apical patency (subgroup A2) and with master apical file (subgroup A1). While, when $\mathrm{NaoCl}$ used with master apical file and apical patency and increase one size filing (subgroup A3), there was no significant difference between anterior and posterior teeth (Table 2). 
TABLE (2) Comparison between the studied groups and subgroups in anterior and posterior teeth with different irrigating protocols and techniques

\begin{tabular}{|c|c|c|c|c|c|c|}
\hline Groups & Subgroups & $\begin{array}{c}\text { Statistical } \\
\text { Analysis }\end{array}$ & $\begin{array}{l}\text { Subgroup A } \\
\quad \text { NaOCl } \\
\mathrm{N}=15\end{array}$ & $\begin{array}{c}\text { Subgroup B } \\
\mathrm{NaOCI}+\mathrm{H} 2 \mathrm{O} 2 \\
\mathrm{~N}=15\end{array}$ & $\begin{array}{c}\text { Subgroup C } \\
\text { NaOCl + EDTA } \\
\quad \text { N = 15 }\end{array}$ & $\mathbf{p}$ \\
\hline \multirow{7}{*}{ 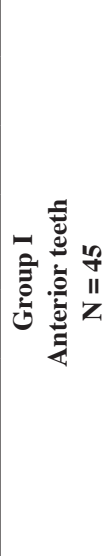 } & \multirow{2}{*}{$\begin{array}{c}\text { Subgroup 1 } \\
\text { Irrigating solution + MAF } \\
\mathrm{N}=5\end{array}$} & Mean \pm SD & $6.77 \pm 7.36$ & $4.73 \pm 3.89$ & $3.18 \pm 1.60$ & \multirow{2}{*}{0.756} \\
\hline & & Median (Range) & $2.62(2.28-19.42)$ & $2.26(1.61-10.36)$ & $3.01(1.60-5.84)$ & \\
\hline & \multirow{2}{*}{$\begin{array}{c}\text { Subgroup 2 } \\
\text { Irrigating solution + MAF + } \\
\text { Apical patency } \\
\mathbf{N}=\mathbf{5}\end{array}$} & Mean \pm SD & $1.63 \pm 1.74$ & $1.04^{\mathrm{a}} \pm 1.19$ & $1.23^{\mathrm{a}} \pm 0.57$ & \multirow[b]{2}{*}{0.833} \\
\hline & & Median (Range) & $0.90(0.0-4.22)$ & $0.92(0.0-3.02)$ & $1.12(0.64-1.94)$ & \\
\hline & \multirow{2}{*}{$\begin{array}{c}\text { Subgroup } 3 \\
\text { Irrigating solution + MAF + } \\
\text { Apical patency + Increase one } \\
\text { size filing } \\
\mathrm{N}=5\end{array}$} & Mean \pm SD & $12.40 \pm 3.70$ & $1.04^{\mathrm{a}} \pm 1.53$ & $0.96^{\mathrm{a}} \pm 0.46$ & \multirow[b]{2}{*}{0.207} \\
\hline & & Median (Range) & $1.50(0.90-12.40)$ & $0.55(0.0-3.68)$ & $0.99(0.44-1.67)$ & \\
\hline & \multicolumn{2}{|l|}{$\mathbf{p}_{\text {Ant. }}$} & 0.185 & $0.044^{*}$ & $0.021^{*}$ & \\
\hline \multirow{7}{*}{ 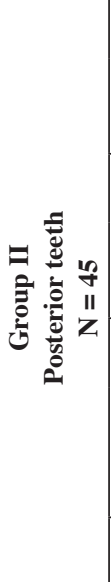 } & \multirow{2}{*}{$\begin{array}{c}\text { Subgroup 1 } \\
\text { Irrigating solution + MAF } \\
\mathrm{N}=5\end{array}$} & Mean \pm SD & $25.16 \pm 16.77$ & $22.38 \pm 23.27$ & $14.64 \pm 13.89$ & \multirow[b]{2}{*}{0.527} \\
\hline & & Median (Range) & $21.34(8.57-50.68)^{\#}$ & $15.27(7.76-63.33)^{\#}$ & $\begin{array}{c}14.71(0.49- \\
36.54)\end{array}$ & \\
\hline & \multirow{2}{*}{$\begin{array}{c}\text { Subgroup 2 } \\
\text { Irrigating solution + MAF + } \\
\text { Apical patency } \\
\mathbf{N}=\mathbf{5}\end{array}$} & Mean \pm SD & $16.43 \pm 9.06$ & $16.11 \pm 18.70$ & $9.99 \pm 10.02$ & \multirow[b]{2}{*}{0.379} \\
\hline & & Median (Range) & $12.73(7.30-30.10)^{\#}$ & $6.01(3.25-48.14)^{\#}$ & $8.92(0.67-26.60)$ & \\
\hline & \multirow{2}{*}{$\begin{array}{c}\text { Subgroup } 3 \\
\text { Irrigating solution + MAF + } \\
\text { Apical patency + Increase one } \\
\text { size filing } \\
\mathrm{N}=5\end{array}$} & Mean \pm SD & $6.40^{\mathrm{ab}} \pm 3.62$ & $11.55 \pm 11.86$ & $4.35 \pm 3.29$ & \multirow[b]{2}{*}{0.330} \\
\hline & & Median (Range) & $4.42(2.14-10.0)$ & $8.10(3.97-32.40)^{\#}$ & $3.80(0.23-8.37)$ & \\
\hline & \multicolumn{2}{|l|}{$\mathbf{p}_{\text {Post. }}$} & $0.027^{*}$ & 0.403 & 0.264 & \\
\hline \multicolumn{3}{|c|}{$p_{1}$} & $0.028^{*}$ & $0.028^{*}$ & 0.175 & \\
\hline \multicolumn{3}{|c|}{$\mathbf{p}_{2}$} & $0.009^{*}$ & $0.009^{*}$ & 0.076 & \\
\hline \multicolumn{3}{|c|}{$\mathbf{p}_{3}$} & 0.175 & $0.009^{*}$ & 0.117 & \\
\hline
\end{tabular}

p: $\mathrm{p}$ value for Kruskal Wallis test for comparing between the different studied subgroups

$\mathrm{p}_{\text {Ant: }}: \mathrm{p}$ value for Kruskal Wallis test for comparing between the different subgroups in each subgroup (Group I anterior) $\mathrm{p}_{\text {Post. }}$ : $\mathrm{p}$ value for Kruskal Wallis test for comparing between the different subgroups in each group (Group II posterior) $\mathrm{p}_{1}$ : $\mathrm{p}$ value for Mann Whitney test for comparing between anterior and posterior in subgroup 1

$\mathrm{p}_{2}$ : $\mathrm{p}$ value for Mann Whitney test for comparing between anterior and posterior in subgroup 2

$\mathrm{p}_{3}$ : $\mathrm{p}$ value for Mann Whitney test for comparing between anterior and posterior in subgroup 3

a: Significant with subgroup 1 in the same subgroup anterior or posterior

b: Significant with subgroup 2 in the same subgroup anterior or posterior

\#: Significant between anterior and posterior in the same subgroups in each subgroup

*: Statistically significant at $\mathrm{p} \leq 0.05$ 
In $\mathrm{NaoCl}$ and $\mathrm{H} 2 \mathrm{O} 2$ subgroup (Subgroup B), there was a significant difference between anterior and posterior teeth when comparing $\mathrm{NaoCl}$ used with master apical file (subgroup B1), with master apical file and apical patency (subgroup B2) and with master apical file, apical patency and increase one size filing (subgroup B3) (Table 2).
In $\mathrm{NaoCl}$ and EDTA subgroup (Subgroup C), there was no significant difference between anterior and posterior teeth when comparing $\mathrm{NaoCl}$ used with master apical file (subgroup C1), with master apical file and apical patency (subgroup C2) and with master apical file, apical patency and increase one size filing (subgroup C3) (Table 2).

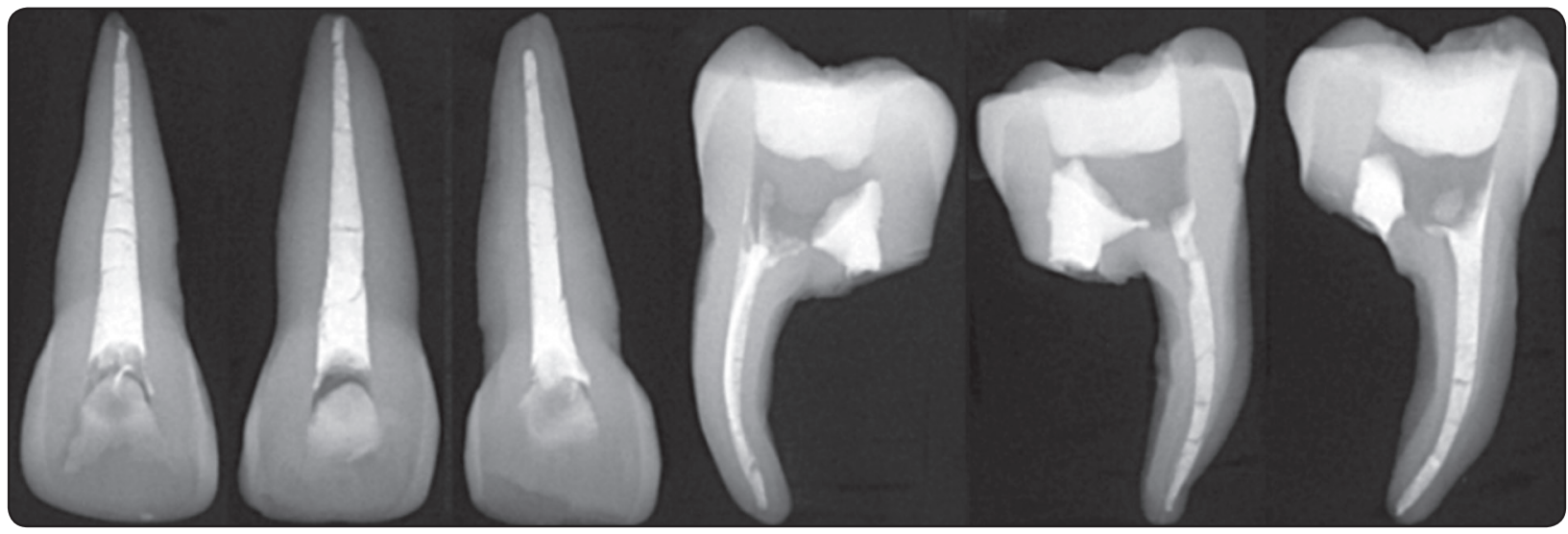

Fig. (1) Anterior and posterior teeth with $\mathrm{Ca}(\mathrm{OH}) 2$ inside the canals

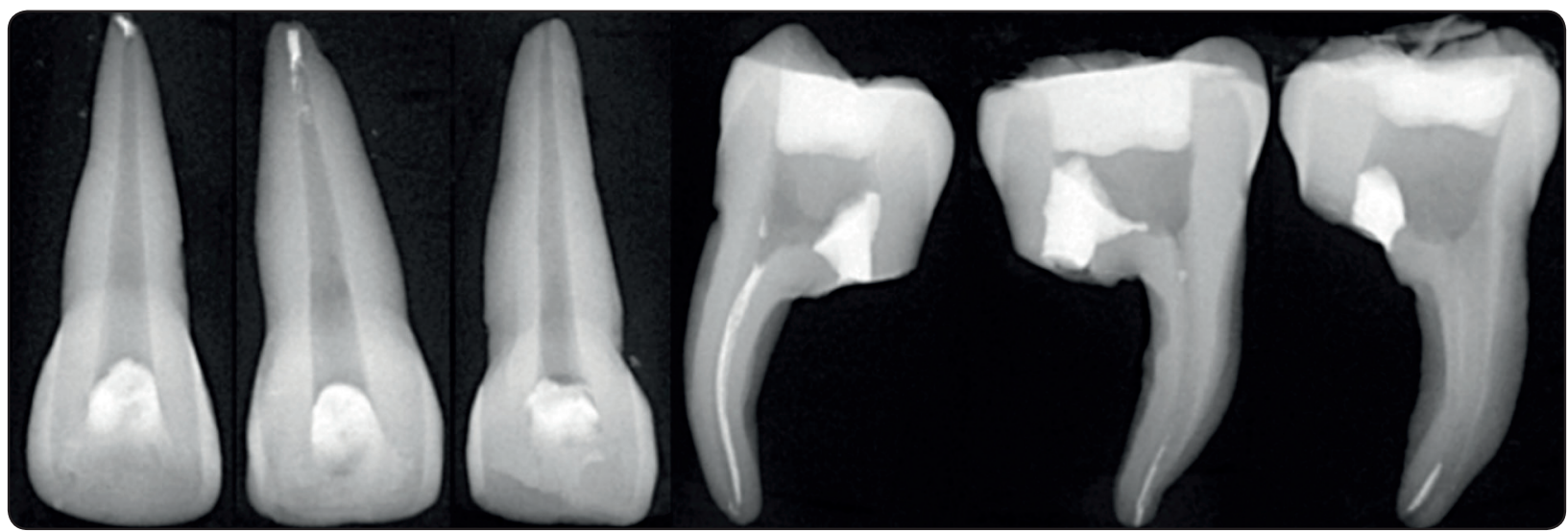

Fig. (2) Anterior and posterior teeth after removal of $\mathrm{Ca}(\mathrm{OH}) 2$ with different protocols and techniques

\section{DISCUSSION}

There are contradictory results in the literature about the necessity of $\mathrm{Ca}(\mathrm{OH}) 2$ removal. However, it is well established that, the residual $\mathrm{Ca}(\mathrm{OH}) 2$ should be removed because of its influence on bonding and sealing of endodontic materials ${ }^{[6,22]}$. Because $\mathrm{Ca}(\mathrm{OH}) 2$ is an inorganic substance, the tissue dissolving capacity of $\mathrm{NaOCl}$ cannot play a role in the process ${ }^{[23]}$. Studies have reported that, the removal of $\mathrm{Ca}(\mathrm{OH}) 2$ medicament from the apical part of the root canal wall is very difficult ${ }^{[6,12]}$. The removal of $\mathrm{Ca}(\mathrm{OH}) 2$ medicament is usually accomplished through several irrigants rinses in conjunction with instrumentation and/or ultrasonics. However, in the endodontic literature there is not a well-defined irrigation protocol to 
adopt for the elimination of $\mathrm{Ca}(\mathrm{OH}) 2$ by chemical action alone. Literature search shows that, hand filing with saline or $\mathrm{NaOCl}$ irrigation does not remove calcium hydroxide completely from the canal. Whereas, EDTA and hand filing improved the removal efficiency ${ }^{[10]}$. Calt \& Serper in 1999 ${ }^{[8]}$ reported complete removal of $\mathrm{Ca}(\mathrm{OH}) 2$ from the root canal after irrigation with EDTA and $\mathrm{NaOCl}$ in comparison with $\mathrm{NaOCl}$ alone. It is likely that, EDTA may chelate residual $\mathrm{Ca}(\mathrm{OH}) 2$ which is then more easily removed by irrigation with $\mathrm{NaOCl}$.

The results of the present study indicated that, the use of master apical file, apical patency and increase one size filing (subgroup 3) with the combination of EDTA and $\mathrm{NaOCl}$ were more effective in removing $\mathrm{Ca}(\mathrm{OH}) 2$ in anterior \& posterior teeth. This finding was in accordance with Camargo et al in $2016^{[24]}$ who reported that, the use of master apical file; foraminal debridment and $5 \mathrm{ml}$ of saline solution applied with the NaviTip irrigation needle in addition to $0.5 \mathrm{~mL}$ of $17 \%$ EDTA was used for 3 minutes was more efficient in removing a $\mathrm{Ca}(\mathrm{OH})_{2}$-chlorhexidine paste from the root canal. Gorduysus et al $2012^{[25]}$ also reported that, it is essential to re-instrument the root canal walls using instrumentation techniques while irrigating with $\mathrm{NaOCl}$ and EDTA combination to improve the removal of calcium hydroxide from inside the canal.

Previous studies showed that, using a combination of EDTA and $\mathrm{NaOCl}$ as a final rinse did not play an important role in the removal of $\mathrm{Ca}(\mathrm{OH}) 2$ residues from the dentin walls ${ }^{[12,16]}$. Also Kuga et al in 2010 ${ }^{[26]}$ stated that, the irrigating solutions used as a final rinse did not play an important role in the removal of $\mathrm{Ca}(\mathrm{OH}) 2$ residues from the dentin walls. The differences between these studies and the results of the present study could be originated from the use of master apical file, apical patency and increase one size filing with the combination of EDTA and $\mathrm{NaOCl}$ irrigating solutions. This was in accordance with Uzunoglu et al in $2014{ }^{[27]}$ who suggested that, the addition of hand instrumentation to irrigation is more effective in removing $\mathrm{Ca}(\mathrm{OH}) 2$ from the root canal than irrigation alone.

The remaining calcium hydroxide was found to be packed mainly in the apical thirds of about 2 to 3 $\mathrm{mm}$ in $\mathrm{NaoCl}$ subgroup (Subgroup A), with master apical file alone (subgroup A1) in both anterior \& posterior teeth.

\section{CONCLUSION}

Under the tested conditions of this study, the most successful method of $\mathrm{Ca}(\mathrm{OH}) 2$ removal was the use of master apical file (hand or rotary), apical patency and increase one size filing with the combination of EDTA and $\mathrm{NaOCl}$ irrigation in both anterior \& posterior teeth.

\section{REFERENCES}

1. Itoh A, Higuchi $\mathrm{N}$, Minami $\mathrm{G}$ et al. A survey of filling methods, intracanal medications, and instrument breakage. Endod J 1999; 25: 823-4.

2. Siqueira JF, Lopes HP. Mechanisms of antimicrobial activity of calcium hydroxide: a critical review. Int Endod J 1999; 32: 361-9.

3. Fava LRG, Saunders WP. Calcium hydroxide pastes: classification and clinical indications. Int Endod J. 1999 Apr; 32(4):257-82.

4. Safavi KE, Nichols FC: Effect of calcium hydroxide on bacterial lipopolysaccharide, Endod J 1993; 19:76.

5. Safavi KE, Nichols FC: Alteration of biological properties of bacterial lipopolysaccharide by calcium hydroxide treatment, Endod J 1994; 20:127.

6. Kim SK, Kim YO. Influence of calcium hydroxide intracanal medication on apical seal. Int Endod J. 2002 Jul; 35(7):623-8.

7. Barbizam JV, Trope M, Teixeira EC, Tanumaru-Filho M, Teixeira FB. Effect of calcium hydroxide intracanal dressing on the bond strength of a resin-based endodontic sealer. Braz Dent J 2008; 19: 224-7.

8. Calt $\mathrm{S}$, Serper. A Dentinal tubule penetration of root canal sealers after root canal dressing with calcium hydroxide. Endod J 1999; 25: 431-3.

9. Hosoya N, Kurayama H, Iino F, Arai T. Effects of calcium hydroxide on physical and sealing properties of canal sealers. Int Endod J 2004; 37: 178-84. 
10. Nandini S, Velmurugan N, Kandaswamy D. Removal efficiency of calcium hydroxide intracanal medicament with two calcium chelators: volumetric analysis using spiral CT, an in vitro study. Endod J 2006; 32: 1097-101.

11. Lambrianidis T, Margelos J, Beltes P. Removal efficiency of calcium hydroxide dressing from the root canal. Endod J 1999; 25: 85-8.

12. Lambrianidis T, Kosti E, Boutsioukis C, Mazinis M. Removal efficacy of various calcium hydroxide/ chlorhexidine medicaments from the root canal. Int Endod J 2006; 39: 55-61.

13. Salgado RJ, Moura-Netto C, Yamazaki AK, Cardoso LN, de Moura AA, Prokopowitsch I. Comparison of different irrigants on calcium hydroxide medication removal: microscopic cleanliness evaluation. Oral Surg Oral Med Oral Path Oral Rad and Endod J 2009; 107:580-4.

14. Jingzhi Ma, Ya Shen, Yan Yang, Yuan Gao, Pan Wan, Yan Gan, Payal Patel, Allison Curtis, Mehrzad Khakpour, Markus Haapasalo. In Vitro Study of Calcium Hydroxide Removal from Mandibular Molar Root Canals. Endod J 2015; April V. 41, Issue 4: 553-558.

15. Ying Song, Jing-zhi Ma, Ru-yan Wang, Xue dong Zhou, Ling Zou, Yuan Gao. Calcium hydroxide removal in curved root canals with apical transportation In Vitro. J of Huazhong Uni of Sci and Tech [Medical Sciences] 2014; August, Volume 34, Issue 4: 608-611.

16. Rodig T, Vogel S, Zapf A, et al. Efficacy of different irrigants in the removal of calcium hydroxide from root canals. Int Endod J 2010; 43:519-27.

17. Balvedi R. P. A., Versiani M. A., Manna F. F. \& Biffi J. C. G. A comparison of two techniques for the removal of calcium hydroxide from root canals. Int Endod J 2010; 43: 763-768.

18. T. Taşdemir, D. Çelik, K. Er, T. Yildirim, K. T. Ceyhanli and C. Yeşilyurt. Efficacy of several techniques for the removal of calcium hydroxide medicament from root canals. Int Endod J 2011; June Volume 44, Issue 6: 505-509.

19. Evren Ok, Altunsoy M, Tanriver M. \& Çapar I.D. Effectiveness of different irrigation protocols on calcium hydroxide removal from simulated immature teeth after apexification. Acta Biomat Odont Scand 2015; Volume 1, Issue 1: 1-5

20. Onoda H.K, Yoshinari G.H, Pereira K.F.S, Delben A.A.S.T., Zárate P., Guerisoli D.M.Z. The persistence of different calcium hydroxide paste medications in root canals: an SEM study. Dent Press Endod J 2011 aprjune;1(1):77-81.

21. Capar, I.D. , Ozcan, E., Arslan, H., Ertas, H., Aydinbelge, H.A. Effect of Different Final Irrigation Methods on the Removal of Calcium Hydroxide from an Artificial Standardized Groove in the Apical Third of Root Canals. Endod J 2014 March; Volume 40, Issue 3: 451-454.

22. Amin SA, Seyam RS, El-Samman MA. The effect of prior calcium hydroxide intracanal placement on the bond strength of two calcium silicate-based and an epoxy resin based endodontic sealer. Endod J 2012; 38:696-9.

23. van der Sluis LWM, Wu MK, Wesselink PR. The evaluation of removal of calcium hydroxide paste from an artificial standardized groove in the apical root canal using different irrigation methodologies. Int Endod J. 2007 Jan;40(1):52-7.

24. Camargo,C.H.R., Leal, F.M., Silva, G.O., De Oliveira, T.R., Madureira, P.G., Camargo, S.E.A. Efficacy of different techniques for removal of calcium hydroxide; chlorhexidine paste from root canals. General Dentistry 2016; Volume 64, Issue 2, Pages e9-e12.

25. Gorduysus, M., Yilmaz, Z., Gorduysus, O., Atila, B., Karapinar, S.O. Effectiveness of a new canal brushing technique in removing calcium hydroxide from the root canal system: A scanning electron microscope study. Conservative Dentistry J 2012; Volume 15, Issue 4, October, 367-371.

26. Kuga M.C.; Tanumaru-Filho M; Faria G.; So M.V.R.; Galletti T. \& Bavello J.R.S. Calcium Hydroxide Intracanal Dressing Removal with Different Rotary Instruments and Irrigating Solutions: A Scanning Electron Microscopy Study. Bra z Dent J 2010; 21(4): 310-314.

27. Uzunoglu M.; Eymirli A.; Uyanik M.O.; Çalt S; Nagas E. Calcium hydroxide dressing residues after different removal techniques affect the accuracy of Root-ZX apex locator. Rest Dent \& Endod J 2014; September 11: 1-6. 